\title{
Corrigendum / Erratum / Retraction
}

\section{RETRACTION TO:}

Yanmi, A. (2019). Improved thematic learning outcomes used the STAD type cooperative model. Jurnal Konseling dan Pendidikan, 7(1). DOI: https://doi.org/10.29210/128600.

\section{This article has been retracted by Publisher based on the following reason:}

The Editor of JKP: Jurnal Konseling dan Pendidikan found the double publication in the article publishing due to article's content similarity published in http://journal-litbang-rekarta.co.id/index.php/jartika/article/view/21

Yanmi, A. C. (2019). Peningkatan hasil belajar tematik menggunakan model kooperatif STAD peserta didik kelas 1 SD. Jurnal Riset Teknologi dan Inovasi Pendidikan, 2(1), 38-44.

One of the conditions of submission of paper for publication in this journal is that authors declare explicitly that their work is original and has not appeared in a publication elsewhere. Reuse of any data should be appropriately cited. As such this article represents a severe abuse of the scientific publishing system. The scientific community takes a very strong view on this matter and apologies are offered to readers of the journal that this was not detected during the submission process. 